\title{
Experimental assessment of organic carbon fluxes in the scleractinian coral Stylophora pistillata during a thermal and photo stress event
}

\author{
Pascale Tremblay ${ }^{1, *}$, Malik S. Naumann ${ }^{1,2}$, Séverine Sikorski ${ }^{1}$, Renaud Grover $^{1, * *}$, \\ Christine Ferrier-Pagès ${ }^{1, * *}$
}

${ }^{1}$ Centre Scientifique de Monaco, Avenue St-Martin, 98000 Monaco, Monaco

${ }^{2}$ Present address: Coral Reef Ecology Group (CORE), University of Bremen \& Leibniz Center for Tropical Marine Ecology (ZMT) GmbH, Fahrenheitstrasse 6, 28359 Bremen, Germany

\begin{abstract}
We assessed pico- and nanoplankton grazing rates as well as dissolved free amino acid (DFAA) uptake rates by the symbiotic coral Stylophora pistillata exposed to thermal and photo stress with concomitant bleaching. The aim was to determine whether these types of food sources could maintain the daily energetic requirements of this coral species. Moreover, the total organic carbon (TOC) flux was measured to quantify bulk C loss or gain. Under control conditions $\left(27^{\circ} \mathrm{C}\right.$ and $200 \mu \mathrm{mol}$ photons $\left.\mathrm{m}^{-2} \mathrm{~s}^{-1}\right)$, autotrophic $\mathrm{C}$ acquisition covered more than $90 \%$ of the respiratory needs of non-bleached corals. Another $10.6 \%$ of the respiratory needs were covered by pico- and nanoplankton grazing. Net TOC flux rates were negative, indicating substantial TOC uptake by the corals. After the stress $\left(31^{\circ} \mathrm{C}\right.$ and $300 \mu \mathrm{mol}$ photons $\left.\mathrm{m}^{-2} \mathrm{~s}^{-1}\right)$, the contribution of autotrophic $\mathrm{C}$ to the respiratory demand decreased to $64 \%$ in bleached corals. Pico- and nanoplankton grazing covered only 2 and $7 \%$ of the respiratory needs during and after the stress, respectively. These findings demonstrate a substantial stress-induced impact on auto- and heterotrophic capacities for energy acquisition in this species. Although no significant change occurred in the DFAA uptake rates, a significant change in the TOC flux direction was observed, which resulted in TOC net release. Consequently, autotrophy and heterotrophy were less efficient in sustaining the respiratory needs of bleaching and bleached $S$. pistillata, suggesting that this coral species, and possibly other related species, can be severely endangered by reoccurring and widespread bleaching events.
\end{abstract}

KEY WORDS: Coral bleaching · Temperature stress · Light stress · Picoplankton · Nanoplankton · Dissolved free amino acids · Total organic carbon

\section{INTRODUCTION}

Tropical scleractinian corals have adapted to their oligotrophic environment by developing a symbiosis with dinoflagellates of the genus Symbiodinium, i.e. zooxanthellae. These dinoflagellates transfer most of their photosynthetically acquired $\mathrm{C}$ to the coral host (Muscatine et al. 1981), as well as other essential nutrients such as nitrogen and phosphorus taken up from the surrounding waters (Grover et al. 2002, 2003). Therefore, they make a large contribution to the growth and metabolic requirements of their host (Muscatine et al. 1981, McCloskey \& Muscatine 1984). Over the past $30 \mathrm{yr}$, however, corals have suffered from mass bleaching events, i.e. the loss of symbionts and/or pigments (Hoegh-Guldberg \& Smith 1989, Douglas 2003), induced by environmental stresses such as elevated seawater temperature 
and irradiance (Glynn 1996, Hughes et al. 2003, Hoegh-Guldberg 2011). A major impact of bleaching on the energetic budget of corals is the reduction or complete loss of photosynthates and other nutrients gained through autotrophy (Hoegh-Guldberg \& Smith 1989, Iglesias-Prieto et al. 1992, Brown 1997), followed by a decrease in coral biomass (Grottoli et al. 2004). As a consequence, bleaching events have often resulted in large-scale coral mortality and the subsequent degradation of reef communities (Hoegh-Guldberg 1999, Buddemeier et al. 2004).

However, within a bleaching-affected reef area, the severity of bleaching differs from one coral species to another, as some species are not affected or bleach and recover, while others bleach and die rapidly as a result of the stress (Marshall \& Baird 2000, Stimson et al. 2002). It has been found that even adjacent colonies of the same species can either bleach or display normal coloration (Edmunds 1994). The underlying mechanisms for the observed different responses are still largely unknown but may be due to interactive effects of increased temperature and irradiance (Lesser \& Farrell 2004) or to the physiological acclimatization of both host and algae (Edge et al. 2005). It can also be a result of species-specific differences in tissue thickness (Hoegh-Guldberg 1999) or growth form, as massive corals are likely to recover faster than branching species (Marshall \& Baird 2000, Loya et al. 2001), and may be affected by the Symbiodinium genotype, some being more thermo-tolerant than others (Baker et al. 2004, Rowan 2004, Berkelmans \& van Oppen 2006). Recently, the coral host was found to actively support resilience to bleaching, either through the expression or upregulation of heat-shock proteins and other antioxidant enzymes (Lesser \& Farrell 2004, Morgan et al. 2005), through the use of its tissue reserves (Grottoli et al. 2004, 2006), or through its heterotrophic plasticity (Grottoli et al. 2006, Anthony et al. 2009, FerrierPagès et al. 2010). It has indeed been demonstrated that, for example, colonies of Montipora capitata are able to recover faster from bleaching than colonies of Porites compressa and P. lobata because of an ability to increase their feeding rates on zooplankton (Grottoli et al. 2006). Zooplankton feeding has also been shown to generally maintain rates of key physiological processes in scleractinian corals (Borell et al. 2008, Ferrier-Pagès et al. 2010, 2011, Naumann et al. 2011), and to increase lipid reserves in healthy and bleached corals (Treignier et al. 2008, Tolosa et al. 2011).

In addition to zooplankton, corals are able to prey on a wide range of other food sources, including pico- and nanoplankton cells with a size of $<5 \mu \mathrm{m}$ (Houlbrèque et al. 2004), as well as dissolved organic matter (DOM) (Grover et al. 2008). In contrast to zooplankton, which generally occur in low abundances in reef waters $\left(2\right.$ organisms $\left.1^{-1}\right)$, except for vertical nocturnal migrations (Yahel et al. 2005), pico- and nanoplankton constitute a continuously available and large biomass pool in reef surrounding waters ( $>10^{5}$ cells ml $^{-1}$; Ferrier-Pagès \& Gattuso 1998) and may therefore represent an important food source for corals during bleaching events. However, only a few studies have measured grazing rates by tropical scleractinian corals for such minute particles (Sorokin 1991, Bak et al. 1998, Ferrier-Pagès \& Gattuso 1998, Houlbrèque et al. 2004), and none of the mentioned studies has been carried out over the course of a bleaching event. DOM also represents one of the largest reservoirs of organic $\mathrm{C}$ on earth (Hedges 1992) and is an important food source for various reef organisms (Coffroth 1984, Wild et al. 2005, Naumann et al. 2010b). For corals, DOM uptake has been documented in particular in the form of dissolved free amino acids (DFAAs) (Ferrier 1991, Al-Moghrabi et al. 1993, Grover et al. 2008). Although DFAAs in seawater can be at significant concentrations, ranging between 0.02 and $1 \mu \mathrm{M}$ (Palenik \& Morel 1990, Ferrier 1991, Bronk 2002), and have been shown to provide up to $21 \%$ of the tissue nitrogen requirements in corals (Grover et al. 2008), the uptake of DFAAs or other dissolved compounds during a bleaching event has not yet been investigated.

Healthy corals can also lose up to $45 \%$ of photosynthetically fixed $\mathrm{C}$ by the release of particulate organic matter (POM), mainly as mucus, and DOM, constituting a significant fraction of their $\mathrm{C}$ and $\mathrm{N}$ budgets (Bythell 1988, Ferrier-Pagès et al. 1998, Wild et al. 2010). Fed corals tend to increase their dissolved organic carbon (DOC) release (Ferrier-Pagès et al. 1998), hence regulating their $C$ input and output. Some previous studies have indicated an increased particulate organic carbon (POC) release by heat-stressed or bleached corals (Kato 1987, Fitt et al. 2009, Niggl et al. 2009, Wooldridge 2009). This increased mucus release was suggested to represent either a host strategy to limit photoinhibition of its zooxanthellae symbionts, or a deleterious consequence of cell membrane disruption (Wooldridge 2009). However, as another study on Stylophora pistillata detected no bleaching-induced changes of generally low rates of mucus (POC) release, the physiological response of corals to thermal stress may indeed be more species-specific than previously assumed (Fitt et al. 2009). 
To improve our understanding of the physiological response of corals to thermal and photo stress in anticipation of more frequent and severe coral bleaching events (Donner et al. 2005), our study assessed the capacity of the branching scleractinian species Stylophora pistillata to retrieve and retain essential nutrients through heterotrophy when deprived of most of its autotrophic inputs. In the Red Sea, this species occurs both in surface and deep waters (McCloskey \& Muscatine 1984, Mass et al. 2010) and presents a gradient of heterotrophy (Muscatine et al. 1989). To this end, key metabolic and energy loss/ gain processes were investigated by laboratory measurements assessing photosynthesis, respiration, suspension feeding (pico- and nanoplankton grazing), DFAA uptake, as well as total organic carbon (TOC) net fluxes in control, bleaching and bleached specimens.

\section{MATERIALS AND METHODS}

\section{Biological material}

A total of 150 nubbins were prepared by cutting the apical branches of 10 colonies (15 nubbins per colony) of the scleractinian coral Stylophora pistillata (Esper 1797, Pocilloporidae) and attaching them to nylon threads. Nubbins from each colony were then distributed over six $20 \mathrm{l}$ tanks $(\mathrm{n}=18$ per tank in 3 control tanks and $n=32$ in each of 3 experimental tanks) and maintained for $3 \mathrm{wk}$ until tissue entirely covered the skeleton at the sites of fracture. During this healing period, nubbins were fed twice a week with Artemia salina nauplii and the amount of nauplii was adjusted to the number of nubbins (2000 nauplii per nubbin). Coral nubbins were maintained under an irradiance of $200 \mu \mathrm{mol}$ photons $\mathrm{m}^{-2} \mathrm{~s}^{-1}$ (12 h light:12 h dark cycle) in an open flowthrough system supplied with freshly pumped seawater (renewal rate of $50 \% \mathrm{~h}^{-1}$ ). Water temperature was adjusted to $27 \pm 0.5^{\circ} \mathrm{C}$ using heaters connected to electronic controllers. Levels of inorganic and organic nutrients in supplied seawater were low (Ferrier-Pagès et al. 2001). After healing, feeding was stopped and nubbins were first maintained 5 wk under controlled conditions before the start of the experiment, to cancel any feeding effect (Grover et al. 2002, Shick et al. 2005, Rodrigues \& Grottoli 2007). The above papers indeed showed that 4 wk after the end of feeding, protein or lipid levels were significantly decreased in the coral tissue, cancelling the feeding effect.

\section{Experimental design}

During the first $5 \mathrm{wk}$, all tanks were kept under the control conditions described above, after which a first sampling (hereafter called C0) of 28 nubbins (9-10 nubbins per tank) was carried out to monitor the set of physiological parameters described below. Three control tanks (CT) were kept under these conditions during the 10 following weeks, after which a final sampling (hereafter called C70) of 24 nubbins (8 nubbins per tank) was performed. In the 3 experimental tanks (hereafter called bleached tank [BT]), after the initial $5 \mathrm{wk}$, temperature and irradiance were gradually increased to $31 \pm 0.5^{\circ} \mathrm{C}\left(+4^{\circ} \mathrm{C}\right.$ in $\left.6 \mathrm{~d}\right)$ and $300 \mu \mathrm{mol}$ photons $\mathrm{m}^{-2} \mathrm{~s}^{-1}$, respectively, to mimic large-scale coral bleaching events, which have been ascribed to increases in sea surface temperature above the summer maximum under bright solar radiation (Drollet et al. 1995, Hoegh-Guldberg 1999, Fitt et al. 2001). These stressful conditions were maintained for $3 \mathrm{wk}$, during which 2 sets of measurements were performed, after $10 \mathrm{~d}$ (called B10 or 'bleaching' samples) and $21 \mathrm{~d}$ (called B21 or 'bleached' samples). For this purpose, at least 24 nubbins (8 nubbins per tank) were sampled at Days 10 and 21, respectively. During the first $2 \mathrm{wk}$ under stress, the onset of coral bleaching was indeed visible, leading to a significant bleaching at the end of the third week. Temperature and light were then decreased over $8 \mathrm{~d}$ back to control conditions and tanks were maintained for 6 additional weeks under these recovery conditions. A final sampling of 24 nubbins (8 nubbins per tank) was performed at the end of the sixth week of recovery, when corals were still bleached and had not recovered (called B70 or long-term bleached samples).

\section{Rates of photosynthesis and respiration}

Measurements were performed at each above described sampling occasion using 6 to 12 nubbins (2 to 4 nubbins per tank). Rates of respiration $(R)$ and net photosynthesis $\left(P_{\mathrm{n}}\right)$ were assessed at $27.0 \pm 0.5^{\circ} \mathrm{C}$ or $31.0 \pm 0.5^{\circ} \mathrm{C}$ (depending on the treatments) and at the following light levels: 0, 100, 200, 300 and $500 \mu \mathrm{mol}$ photons $\mathrm{m}^{-2} \mathrm{~s}^{-1}$, using the respirometry technique (Hoogenboom et al. 2010). Rates of gross photosynthesis $\left(P_{\mathrm{g}}\right)$ were calculated by adding $R$ to $P_{\mathrm{n}}$. Samples were then frozen for later determinations of chlorophyll (chl) and zooxanthellae concentrations. For this purpose, nubbins were thawed and their tissue was detached from the skeleton using an air brush and $0.45 \mu \mathrm{m}$ filtered seawater (FSW). The 
slurry of each nubbin was homogenised individually using a potter tissue grinder and a $500 \mu \mathrm{l}$ subsample was taken for determination of the zooxanthellae concentration according to Rodolfo-Metalpa et al. (2006). The rest of the slurry was centrifuged at $8000 \times g$ for $10 \mathrm{~min}$ at $4^{\circ} \mathrm{C}$ to pellet the zooxanthellae. The pellet was re-suspended in $5 \mathrm{ml}$ of $99 \%$ acetone. Chlorophyll pigments were extracted at $4{ }^{\circ} \mathrm{C}$ over $24 \mathrm{~h}$. The extract was centrifuged at $11000 \times g$ for 15 min and chl $a$ and $\mathrm{chl} c_{2}$ were determined according to the method of Jeffrey \& Humphrey (1975) using a UVmc ${ }^{2}{ }^{\circledR}$ spectrophotometer (Safas, Monaco). Photosynthesis and respiration data were subsequently normalised to the skeletal surface area of each nubbin $\left(\mu \mathrm{mol} \mathrm{O}_{2} \mathrm{~cm}^{-2} \mathrm{~h}^{-1}\right)$, which was measured using the wax-dipping technique (Stimson \& Kinzie 1991).

\section{Feeding on pico- and nanoplankton}

We assessed, for each sampling occasion described above, feeding rates on heterotrophic bacteria (BA), cyanobacteria (CYA), and auto- and heterotrophic picoflagellates (PF) and nanoflagellates (NF). Nubbins (1 to $3 \mathrm{ml}$ in size) were individually incubated in $900 \mathrm{ml}$ Plexiglas flow chambers (Levy et al. 2001, Houlbrèque et al. 2004, Picciano \& Ferrier-Pagès 2007), previously filled with freshly collected seawater, concentrated 5 times on a $1 \mu \mathrm{m}$ filter using a reverse filtration apparatus (Sheldon \& Rassoulzadegan 1987). For each sampling occasion and condition, a total of 6 to 12 nubbins were incubated for $6 \mathrm{~h}$ in the dark (Houlbrèque et al. 2004). For each incubation trial of 3 nubbins, 1 chamber was also kept as control (without nubbins), to estimate the autogenic changes in pico- and nanoplankton concentrations resulting from internal grazing, natural death or growth. These changes were then taken into account in the grazing rate calculations, either considering the control corresponding to each incubation trial or the mean of controls for each condition. Results obtained were equivalent, as the controls did not change substantially. The current velocity was set to $3.6 \mathrm{~cm} \mathrm{~s}^{-1}$, ensuring maximal ingestion rates (Houlbrèque et al. 2004), and seawater temperature was kept at either $27.0 \pm 0.5^{\circ} \mathrm{C}$ or $31.0 \pm 0.5^{\circ} \mathrm{C}$ depending on the condition tested.

Pico- and nanoplankton concentrations were determined from triplicate seawater samples of $10 \mathrm{ml}$ each from every chamber, at the beginning and after 3 and $6 \mathrm{~h}$ incubation. The incubation time was chosen (after preliminary experiments) in order to have a maxi- mum of only a $50 \%$ decrease in prey concentration in the incubation medium and to avoid a complete disappearance of prey. Organisms were fixed with formaldehyde $(0.5 \%$ final concentration), stained with DAPI (\#D9542, Sigma-Aldrich) (Porter \& Feig 1980), filtered onto $0.2 \mu \mathrm{m}$ black Nuclepore ${ }^{\circledR}$ Polycarbonate track-etched membranes (\#110656, Whatman) and frozen at $-20^{\circ} \mathrm{C}$ until further analysis. Organisms were then counted at 1008x magnification using a Leica epifluorescence microscope with UV (for heterotrophic bacteria and flagellates) and blue (for cyanobacteria and autotrophic flagellates) light excitation (Ferrier-Pagès \& Gattuso 1998). Bacteria and heterotrophic flagellates appeared blue under UV excitation (flagellates being larger in size), whereas cyanobacteria and autotrophic flagellates appeared yellow and red, respectively, under the blue light excitation.

Grazing was assessed as clearance rate according to previous studies on gorgonians (Ribes et al. 1998, Ribes et al. 2003), sponges (Ribes et al. 1999) and corals (Houlbrèque et al. 2004, Tremblay et al. 2011), and calculated using the equations of Ribes et al. (1998) derived from the equations of Frost (1972), which take into account the growth or lysis of prey during incubations. A full description of the equations can be found in the above-cited studies. Grazing rates were either expressed as number of prey organisms or as $\mu \mathrm{g} \mathrm{C}$ ingested and normalised to the skeletal surface area, the tissue protein content or the number of polyps of each nubbin. Carbon contents of prey items were used in agreement with previous studies on anthozoan feeding (Houlbrèque et al. 2004, Picciano \& Ferrier-Pagès 2007). Samples for the protein content of the coral tissue were extracted in $1 \mathrm{M} \mathrm{NaOH}$ at $90^{\circ} \mathrm{C}$ for $30 \mathrm{~min}$ and then measured using the BCAssay Protein Quantification Kit (\#UP40840A, Interchim) (Smith et al. 1985), with a Xenius ${ }^{\circledR}$ spectrofluorometer (Safas). The standard curve was established using bovine serum albumin. The total number of polyps was determined using a binocular microscope.

\section{Depletion of DFAAs}

To assess the uptake rates of DFAAs by Stylophora pistillata, an algal mix containing 19 different amino acids (Algal Amino Acid Mixture, \#ULM-2314-1, Lot PR-19236, Larodan Fine Chemicals AB) was dissolved in distilled water to a concentration of $10 \mathrm{mM}$. The DFAA composition of the algal mix was close to that of natural seawater (Grover et al. 2008). Individual 
beakers were filled with $200 \mathrm{ml} \mathrm{FSW}$ and enriched to a final concentration of $3.5 \pm 0.1 \mu \mathrm{M}$ DFAA. The final concentration was precisely determined, taking into account the natural DFAA concentration (equal to $1.27 \pm 0.5 \mu \mathrm{M}$ DFAA) present in the FSW. For each sampling occasion, 3 to 6 beakers were kept as controls, while coral nubbins were added to another 6 to 12 beakers and incubated for $6 \mathrm{~h}$ in the light, according to the respective light intensity of the sampling occasions, and at a constant temperature of $27.0 \pm$ $0.5^{\circ} \mathrm{C}$ or $31.0 \pm 0.5^{\circ} \mathrm{C}$ in a water bath. The incubation medium was continuously stirred using a Tefloncoated magnetic stirrer. DFAA depletion was monitored in each beaker by sampling of $5 \mathrm{ml}$ of medium every hour. Only the first hour was taken into account for the subsequent uptake rate calculations, as depletion was linear during the first $3 \mathrm{~h}$, before decreasing asymptotically, because of the lowering of the DFAA concentrations in the medium (Grover et al. 2008).

DFAA concentrations were quantified using a Xenius ${ }^{\circledR}$ spectrofluorometer (Safas) according to Grover et al. (2008), after Parsons et al. (1984). Prior to fluorescence measurements, seawater samples were filtered through a $0.2 \mu \mathrm{m}$ syringe filter (Minisart, 16532, Sartorius Stedim Biotech) to remove any particles that could interfere, and samples were then excited at $342 \mathrm{~nm}$. Emission wavelengths between 430 and $470 \mathrm{~nm}$ were recorded to quantify the maximal fluorescence intensity (ca. $452 \mathrm{~nm}$ ). Standard solutions of DFAA from 0.5 to $4.0 \mu \mathrm{M}$ were prepared for internal calibration and to set up the photomultiplier voltage. DFAA concentration in the samples was calculated according to the following formula:

$$
[\mathrm{DFAA}]=\left(F_{\mathrm{S}}-F_{\mathrm{B}}\right) \times F
$$

where $F_{\mathrm{S}}$ is the average fluorescence of triplicate seawater samples, $F_{\mathrm{B}}$ is the average fluorescence of triplicate blanks, and $F$ is the conversion factor $(\mathrm{MM} /$ relative fluorescence intensity) according to the calibration curve. Results were normalised to the skeletal surface area, tissue protein content or polyp number and expressed as $\mu \mathrm{mol}$ DFAA or $\mu \mathrm{g}$ C. For this purpose, the $\mathrm{C}$ content as well as the percentage of each amino acid present in the algal mix was taken into account (ca. $58.2 \mu \mathrm{g} \mathrm{C} \mu \mathrm{mol}^{-1}$ DFAA).

\section{TOC net flux}

The established beaker incubation technique (e.g. Wild et al. 2005, Naumann et al. 2010a) was applied to quantify net TOC flux rates for corals at the respective sampling occasions. Prior to measurements
$(24 \mathrm{~h})$, water inflow to all coral maintenance tanks was pre-filtered (50 $\mu \mathrm{m}$ gauze) to reduce variability of measured TOC concentrations due to the possible scattered occurrence and sampling of particles $>50 \mu \mathrm{m}$. The nylon thread attached to each coral nubbin was thoroughly cleaned and coral surfaces were exposed to a smooth stream of seawater inside the cultivation tanks to remove attached organic and inorganic particles immediately before experiments. Corals were transferred without aerial exposure into acid-washed and seawater-rinsed $250 \mathrm{ml}$ glass beakers filled with 180 to $215 \mathrm{ml}$ maintenance tank seawater, fully submerging the corals. Beakers containing corals $(\mathrm{n}=6)$ and control beakers containing only seawater $(n=3)$ were placed in a water bath and incubated at constant temperature (either $27.0 \pm$ $0.5^{\circ} \mathrm{C}$ or $31.0 \pm 0.5^{\circ} \mathrm{C}$ ). Stirring was applied by Tefloncoated magnetic stir bars. The water bath containing the incubation beakers was covered with transparent cellophane foil to avoid contamination by the introduction of airborne particles, leaving 2 side openings for air exchange. Light intensity was adjusted to the respective levels as described above and temperature inside the water bath was continuously monitored. After $6 \mathrm{~h}$, corals were removed from the incubation beakers and transferred back to the maintenance tanks prior to sampling of the incubation media.

Before and after incubations, seawater subsamples were drawn by sterile syringe from the thoroughly homogenised incubation media of coral and control beakers to quantify TOC concentration and zooxanthellae abundance. Zooxanthellae counts were carried out to quantify the possible contribution of zooxanthellae POC released during the incubation period to bulk seawater TOC contents. Sampling times were recorded to relate measured concentration differences to incubation periods. TOC subsamples (17 $\mathrm{ml}, \mathrm{n}=3$ per beaker and sampling) were transferred into pre-combusted $\left(450^{\circ} \mathrm{C}, 5 \mathrm{~h}\right)$ glass vials, acidified with phosphoric acid $(20 \%, 250 \mu \mathrm{l})$ to $\mathrm{pH}<2$ and kept frozen $\left(-20^{\circ} \mathrm{C}\right)$ until analysis by high temperature catalytic oxidation using a TOC analyser (Shimadzu TOC-VCPH; CV maximum $\leq 1.5 \%$, i.e. $\pm 1 \mu \mathrm{mol} \mathrm{C} \mathrm{^{-1 }}$; referenced by Consensus Reference Materials of Hansell Research Laboratory, University of Miami, FL, USA). Zooxanthellae subsamples $(50 \mathrm{ml})$ were immediately fixed with formaldehyde ( $1 \%$ final concentration) plus 2 to 3 drops of Lugol's solution and stored refrigerated $\left(4^{\circ} \mathrm{C}\right)$ pending analysis. Zooxanthellae cell abundance was quantified microscopically in each sample after $48 \mathrm{~h}$ of settlement in Uthermohl chambers. Eventually, zooxanthellae POC release, derived from 
cell counts and cell POC content (Niggl et al. 2009), was found to contribute insignificantly $(<3 \%)$ to TOC net flux, and thus could be considered negligible for the present short incubation periods. For calculation of TOC net flux rates, concentration differences measured from the control beakers were subtracted from those measured in coral beakers and the results were normalised to nubbin-specific skeletal surface area, tissue protein content or polyp number and incubation time. In contrast to the previous measurements, skeletal surface area of all nubbins used in TOC net flux incubations was quantified by advanced geometric techniques in combination with respective approximation factors (Naumann et al. 2009).

\section{Daily carbon acquisition}

Total daily $\mathrm{C}$ acquisitions via autotrophy and microheterotrophy were compared using measurements of photosynthetic and feeding rates. Total daily acquisition through autotrophy $\left(P_{\mathrm{C}}\right)$ was calculated using $P_{\mathrm{g}}$ measured at 200 or $300 \mu \mathrm{mol}$ photons $\mathrm{m}^{-2} \mathrm{~s}^{-1}$ over the $12 \mathrm{~h}$ daylight period, converted to carbon equivalents according to Anthony \& Fabricius (2000), where: $P_{\mathrm{C}}=$ $\mu \mathrm{mol} \mathrm{O}_{2}$ produced $\times 12 / P Q$, and $R_{\mathrm{C}}$ (daily respiration) $=\mu \mathrm{mol} \mathrm{O}_{2}$ consumed $\times 12 \times R Q . P Q$ and $R Q$ are the photosynthetic and respiratory quotients, equal to $1.1 \mathrm{~mol} \mathrm{O}_{2}$ :mol C and $0.8 \mathrm{~mol} \mathrm{C}: \mathrm{mol} \mathrm{O}_{2}$, respectively (Muscatine et al. 1981). The CZAR, or percentage contribution of zooxanthellae acquired $\mathrm{C}$ to daily animal respiration (adopted from Muscatine et al. 1981, Grottoli et al. 2006), was subsequently calculated. C acquisition from feeding of pico- and nanoplankton $\left(H_{\mathrm{C}}\right)$ was assessed based on total grazing rates and considering the relative group-specific $\mathrm{C}$ contents. The daily amount of time spent by Stylophora pistillata on feeding remains an unknown variable. Continuous feeding $(24 \mathrm{~h})$ on pico- and nanoplankton was therefore assumed, as these organisms are continuously present in high concentrations $\left(>10^{5} \mathrm{cells} \mathrm{ml}^{-1}\right)$ in reef waters and are therefore continuously filtered by corals (Ferrier-Pagès \& Gattuso 1998, Houlbrèque et al. 2006). The CHAR, or percentage contribution of heterotrophically acquired $\mathrm{C}$ to daily animal respiration (Grottoli et al. 2006), was consequently deduced from $H_{\mathrm{C}}$.

\section{Statistical analysis}

Physiological parameters, as well as grazing rates, DFAA uptake rates and TOC net fluxes, are reported as means \pm SE. Data were checked for normality using a Kolmogorov-Smirnov test with the Lilliefors correction and for variance homoscedasticity using a Levene's test. When normality was not fulfilled, a data transformation (i.e. In transformation) was performed. The effect of treatment on the different parameters was tested using an ANOVA on before-after, control-impact (BACI) design (Green 1979, StewartOaten et al. 1986, Underwood 1994, Smith 2002), in which the effect of stress was assessed using a comparison between bleached and control tanks. The main factors of interest are treatments (CI; 2 levels, control and bleached) and before-after bleaching event (BA; 2 levels). Time (T[BA]) was nested within before-after, with 1 and 3 levels, respectively. Treatment, before-after and time were fixed factors. The final ANOVA model included the terms BA, CI, BA $\times$ CI and $\mathrm{T}(\mathrm{BA})$. The term of most interest is $\mathrm{BA} \times \mathrm{CI}$, which measures any change associated with bleaching event. The BACI analyses were followed by a parametric post hoc test (Tukey's test) on T(BA), if significant. The tank effect nested within treatment was also tested, but it was not significant, and was therefore not included in the analysis. Differences between factors were considered significant for $\mathrm{p}$-values $<0.05$. Statistics were performed using Systat 13 software.

\section{RESULTS}

\section{Zooxanthellae concentration, chl content and rates of photosynthesis and respiration}

Zooxanthellae and chl concentrations $\left(\mathrm{cm}^{-2}\right)$ remained constant in control corals over the course of the experiment (from $\mathrm{C} 0$ to $\mathrm{C} 70$ ), but temperature and light stress significantly decreased these concentrations (significant interaction $\mathrm{BA} \times \mathrm{CI}_{\text {; }}$ Table 1, Fig. 1a,b). Zooxanthellae concentration was therefore significantly lower in the B21 and B70 bleached corals compared with the B10 corals (Tukey's test on $\mathrm{T}[\mathrm{BA}], \mathrm{p}=0.0007$ and $\mathrm{p}<0.0001$, respectively; Fig. 1a). It was also lower in B70 compared with B21 corals (Tukey's test on T[BA], $p=0.0113$; Fig. 1a). Chl concentration was also significantly lower in the B70 corals compared with the B10 and B21 corals (Tukey's test on T[BA], p < 0.0001; Fig. 1b); however, chl content per symbiont cell remained variable during the experiment (Fig. 1c). Chl a was mainly affected by the increase in temperature and light (Fig. 1d), as its content decreased at the early onset of the bleaching event (B10) and remained low in B21 and B70 nubbins compared with chl $c_{2}$. 
Table 1. Results of ANOVA on the before-after, controlimpact (BACI) design testing the effect of thermal and photo stress on zooxanthellae and chlorophyll concentration per $\mathrm{cm}^{2}$ in Stylophora pistillata. Significant values are in bold

\begin{tabular}{|c|c|c|c|}
\hline Factor & df & $\mathrm{p}$ & $F$ \\
\hline \multicolumn{4}{|l|}{ Zooxanthellae concentration $\left(\mathrm{cm}^{-2}\right)$} \\
\hline Period: Before-After (BA) & 1 & 0.0884 & 3.08 \\
\hline Treatment: Control-Bleach (CI) & 1 & 0.0919 & 3.01 \\
\hline Period $\times$ Treatment $(\mathrm{BA} \times \mathrm{CI})$ & 1 & 0.0030 & 10.24 \\
\hline Times within period (T[BA]) & 2 & $<0.0001$ & 37.78 \\
\hline Error & 34 & - & - \\
\hline \multicolumn{4}{|l|}{ Chlorophyll concentration $\left(\mathrm{cm}^{-2}\right)$} \\
\hline Period: Before-After (BA) & 1 & 0.0518 & 4.13 \\
\hline Treatment: Control-Bleach (CI) & 1 & 0.0049 & 9.34 \\
\hline Period $\times$ Treatment $(\mathrm{BA} \times \mathrm{CI})$ & 1 & 0.0373 & 4.78 \\
\hline Times within period (T[BA]) & 2 & $<0.0001$ & 21.95 \\
\hline Error & 28 & - & - \\
\hline
\end{tabular}

Treatment (CI) and time (T[BA]) had a significant effect on rates of gross photosynthesis, $P_{\mathrm{g}}$ (ANOVA on BACI design, $\mathrm{p}<0.05$ for $\mathrm{CI}$ and T[BA]; Fig. 2a). Indeed, $P_{\mathrm{g}}$ was significantly decreased in B70 nubbins compared with B10 and B21 nubbins (Tukey's test on T[BA], p < 0.05; Fig. 2a). Time had a significant effect on rates of respiration $(p=0.0005$ for T[BA]; Fig. 2b), which were significantly higher in B10 and B21 stressed nubbins compared with B70 nubbins returned to control conditions (Tukey's test on $\mathrm{T}[\mathrm{BA}], \mathrm{p}=0.0009$ and $\mathrm{p}=0.0043$, respectively; Fig. $2 \mathrm{~b})$. In terms of carbon, gross photosynthesis $\left(P_{\mathrm{C}}\right)$ measured at $200 \mu \mathrm{mol}$ photons $\mathrm{m}^{-2} \mathrm{~s}^{-1}$ supplied $161 \pm$ 9 and $147 \pm 15 \mu \mathrm{g} \mathrm{C} \mathrm{cm}{ }^{-2} \mathrm{~d}^{-1}$ to $\mathrm{C} 0$ and $\mathrm{C} 70$ control corals, respectively, but only half of this amount $(86 \pm$ $11 \mu \mathrm{g} \mathrm{C} \mathrm{cm}^{-2} \mathrm{~d}^{-1}$ ) to $\mathrm{B} 70$ nubbins at the same light intensity. The corresponding respiration $\left(R_{\mathrm{C}}\right)$ con-
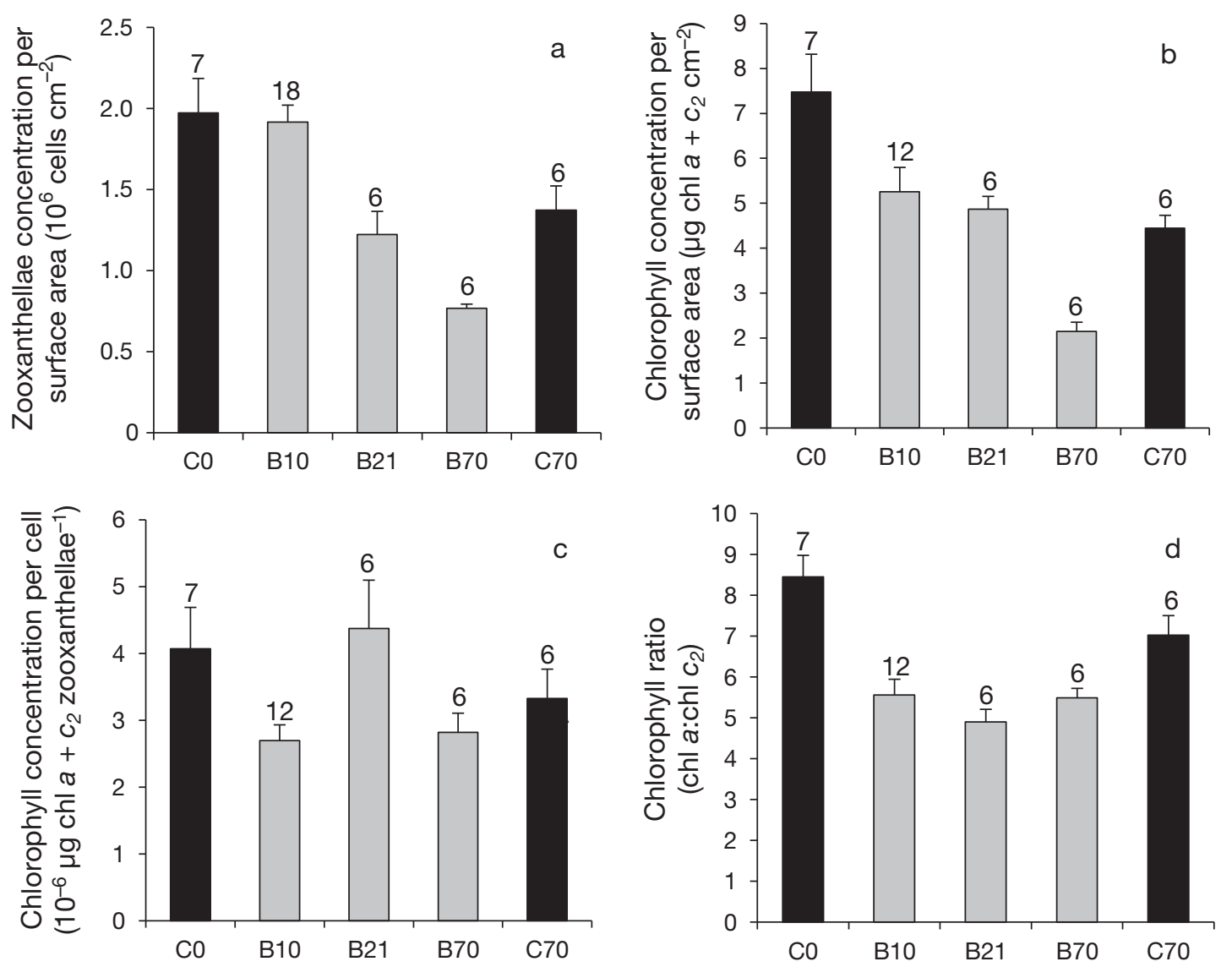

Sampling occasion

Fig 1. (a) Zooxanthellae concentrations per skeletal surface area, (b) chlorophyll (chl) concentrations per skeletal surface area or (c) per cell, and (d) ratio of chl $a$ and $c_{2}$ in Stylophora pistillata over the course of a thermal and light stress event. Data are expressed as means \pm SE and the sample sizes (n) are displayed above the bars. C0 and C70: initial and final sampling, respectively, in control tanks; B10: samples under the bleaching process, taken $10 \mathrm{~d}$ after the start of the thermal and light stress event; B21: bleached samples, taken $21 \mathrm{~d}$ after the start of the thermal and light stress event; B70: long-term bleached samples, taken $6 \mathrm{wk}$ after the end of the thermal and light stress event 

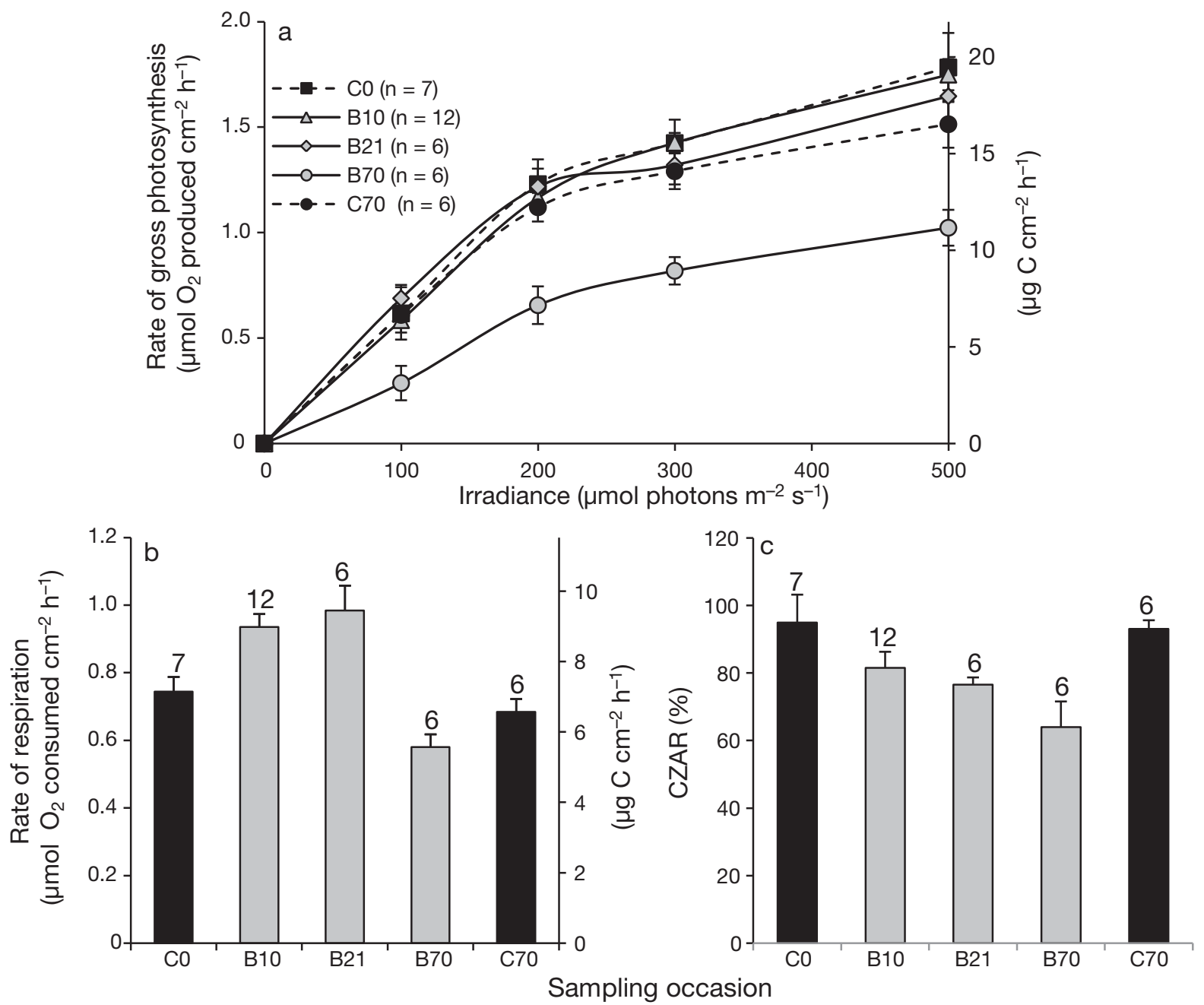

Fig 2. Stylophora pistillata. Rates of (a) gross photosynthesis $\left(P_{\mathrm{g}}\right)$ and (b) respiration $(R)$ expressed as $\mu \mathrm{mol} \mathrm{O}_{2} \mathrm{~cm}^{-2} \mathrm{~h}^{-1}$ or $\mu \mathrm{g} \mathrm{C}$ $\mathrm{cm}^{-2} \mathrm{~h}^{-1}$, and (c) contribution of zooxanthellae acquired C to daily animal respiration (CZAR; \%) in $S$. pistillata over the course of a thermal and light stress event. Data are expressed as means \pm SE and the sample sizes (n) are displayed in each panel. For sample abbreviations, see Fig. 1 legend

sumed $171 \pm 10$ and $158 \pm 9 \mu \mathrm{g} \mathrm{C} \mathrm{cm}{ }^{-2} \mathrm{~d}^{-1}$ for $\mathrm{C} 0$ and C70 corals, respectively, suggesting that the $\mathrm{C}$ losses from respiration were almost entirely balanced by the gains from photosynthesis. In contrast, $134 \pm 9 \mu \mathrm{g}$ $\mathrm{C} \mathrm{cm}{ }^{-2} \mathrm{~d}^{-1}$ was respired in $\mathrm{B} 70$ nubbins, suggesting an unbalanced organic $\mathrm{C}$ budget. Therefore, treatment had a significant effect on CZAR ( $p=0.0006$ for $\mathrm{CI}_{i}$ Fig. 2C), with a lower value for B70 nubbins (64 \pm $8 \%$; Fig. 2c) compared with control corals (95 $\pm 9 \%$ and $93 \pm 3 \%$ for $\mathrm{C} 0$ and $\mathrm{C} 70$, respectively).

\section{Pico- and nanoplankton grazing}

Throughout the following sections, data are expressed per skeletal surface area and per hour.
Equivalent results were found for normalisations per polyp (ca. 28 polyps $\mathrm{cm}^{-2}$ ) and per tissue protein (between 1.1 and $1.5 \mathrm{mg}$ protein $\mathrm{cm}^{-2}$ ).

Pico- and nanoplankton concentrations were similar at the beginning of all incubations, i.e. $5.7 \pm 0.4 \times$ $10^{5}$ bacteria $\mathrm{ml}^{-1}, 1.3 \pm 0.3 \times 10^{4}$ picoflagellates $\mathrm{ml}^{-1}$, $1.8 \pm 0.3 \times 10^{4}$ nanoflagellates $\mathrm{ml}^{-1}$, and $2.7 \pm 0.2 \times$ $10^{4}$ cyanobacteria $\mathrm{ml}^{-1}$. Light and temperature stress induced changes in the pico- and nanoplankton grazing rates, in terms of number of prey ingested ( $p<0.001$ for T[BA]; Fig. 3a-c), except for cyanobacteria grazing rates, which did not change $(p=0.8504$ for $\mathrm{T}[\mathrm{BA}]_{i}$ Fig. 3d). Therefore, B21 corals had an increased grazing rate on bacteria $\left(6.0 \pm 0.4 \times 10^{6}\right.$ cells ingested $\mathrm{cm}^{-2} \mathrm{~h}^{-1}$ or $46 \pm 3 \%$ of the initial concentration; Tukey's test on T[BA], p $<0.01$; Fig. 3a). 

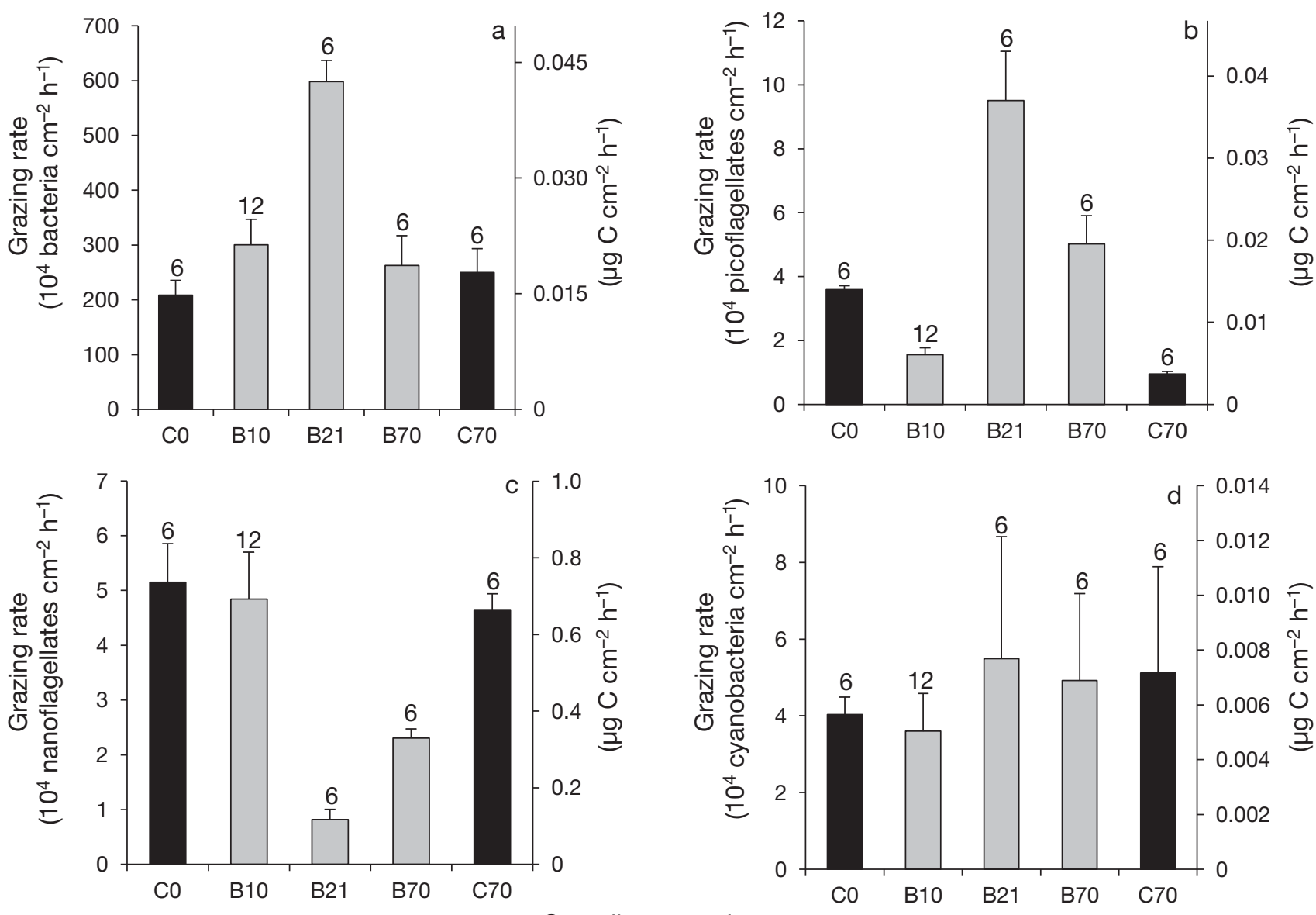

Fig. 3. Stylophora pistillata. Hourly grazing rates of (a) bacteria, (b) auto- and heterotrophic picoflagellates, (c) auto- and heterotrophic nanoflagellates and (d) cyanobacteria expressed as the number of prey or the $\mu \mathrm{g} C$ ingested and normalised to the skeletal surface area in $S$. pistillata over the course of a thermal and light stress event. Data are means \pm SE and the sample sizes (n) are displayed above the bars. For sample abbreviations, see Fig. 1 legend

These B21 corals also had significantly higher picoflagellate grazing rates (Tukey's test on T[BA], p < 0.05 ; Fig. 3b). In contrast, nanoflagellate grazing rates decreased for B21 corals (from $4.8 \pm 0.9 \times 10^{4}$ to $0.8 \pm 0.2 \times 10^{4}$ cells ingested $\mathrm{cm}^{-2} \mathrm{~h}^{-1}$ or from $13 \pm 3 \%$ to $2 \pm 0.5 \%$ of the initial concentration; Tukey's test on T[BA], p < 0.0001; Fig. 3c), and remained low in B70 nubbins $\left(2.3 \pm 0.2 \times 10^{4}\right.$ cells cm $\mathrm{cm}^{-2} \mathrm{~h}^{-1}$ or $6 \pm 1 \%$ of the initial concentration; Fig. 3c). Grazing rates on total picoplankton and nanoplankton cells (Fig. 4a) varied significantly with time ( $p=0.0012$ on T[BA]), as B21 corals were the only ones ingesting significantly more cells (Tukey's test on T[BA], p < 0.01), as they increased their grazing rates on bacteria and picoflagellates. However, because picoplankton have a lower $\mathrm{C}$ content per cell than the larger nanoplankton, the total amount of $\mathrm{C}$ gained through picoplankton and nanoplankton grazing severely decreased in B21 and B70 nubbins $(p=0.0002$ for
T[BA]; Fig. 4b), from 0.7 to $0.2-0.4 \mu \mathrm{g} \mathrm{C} \mathrm{cm}^{-2} \mathrm{~h}^{-1}$ (Tukey's test on T[BA], p $<0.05$; Fig. 4b). Considering that pico- and nanoplankton can be continuously ingested by corals in situ, the mean daily heterotrophic $\mathrm{C}$ input $\left(H_{\mathrm{C}}\right)$ varied between $16.5 \pm 1.0$ and 18.5 $\pm 2.5 \mu \mathrm{g} \mathrm{C} \mathrm{cm}^{-2} \mathrm{~d}^{-1}$ for control (C0 and C70) and B10 corals. $H_{\mathrm{C}}$ was only $4.6 \pm 0.4$ and $8.8 \pm 0.5 \mu \mathrm{g} \mathrm{C} \mathrm{cm}^{-2}$ $\mathrm{d}^{-1}$ for B21 and B70 nubbins, respectively. Therefore, the corresponding CHAR was ca. $10.6 \%$ for control corals $(\mathrm{C} 0$ and $\mathrm{C} 70)$ and varied with time $(\mathrm{p}=0.0072$ for $\mathrm{T}[\mathrm{BA}]_{i}$ Fig. $\left.4 \mathrm{c}\right)$ between $2.0 \pm 0.2 \%$ and $8.1 \pm$ $1.4 \%$ for B10, B21 and B70 nubbins (Fig. 4 c).

\section{DFAA net flux}

Under all conditions, net DFAA flux rates measured between Stylophora pistillata and the surrounding incubation medium were negative, indicating 

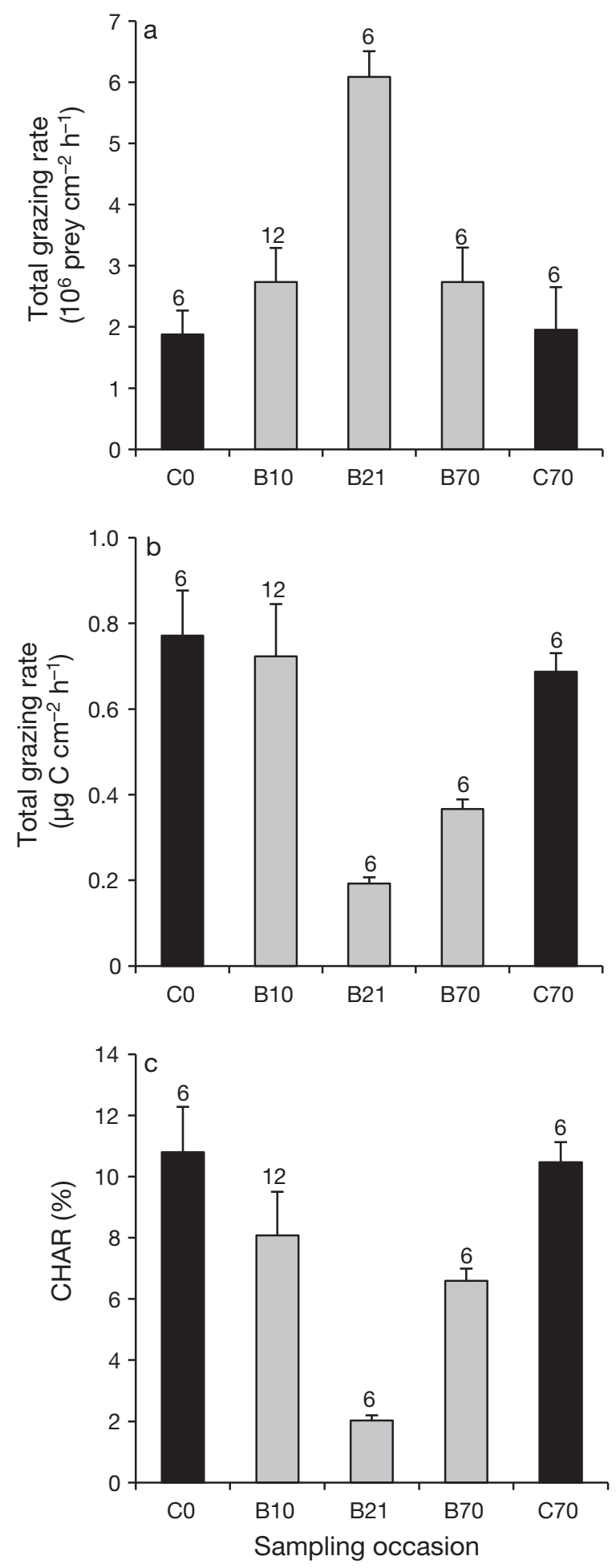

Fig. 4. Stylophora pistillata. Total grazing rates on pico- and nanoplankton expressed as (a) prey $\mathrm{cm}^{-2} \mathrm{~h}^{-1}$ or (b) $\mu \mathrm{g} \mathrm{C} \mathrm{cm}^{-2}$ $\mathrm{h}^{-1}$, and (c) contribution of heterotrophically acquired $\mathrm{C}$ to daily animal respiration $\left(\mathrm{CHAR}_{\mathrm{i}} \%\right)$ in Stylophora pistillata over the course of a thermal and light stress event. Data are means $\pm \mathrm{SE}$ and the sample sizes (n) are displayed above the bars. For sample abbreviations, see Fig. 1 legend
DFAA uptake by the corals (Fig. 5a). This uptake was not significantly different between treatments (Table 2), except for B21 corals, which slightly, but significantly, increased their uptake rates compared with the 4 other sampling occasions (Tukey's test on T[BA], p < 0.0001; Fig. 5a).

\section{TOC net flux}

At initial (C0) and final (C70) control conditions, net TOC flux rates measured between Stylophora pistillata and the surrounding incubation medium were negative $(-0.44 \pm 0.09$ and $-0.30 \pm 0.08 \mu \mathrm{g}$ TOC $\mathrm{cm}^{-2} \mathrm{~h}^{-1}$, respectively), indicating substantial TOC uptake by the corals (Fig. 5b). There was an effect of temperature and light stress on TOC net flux (significant interaction $\mathrm{BA} \times \mathrm{CI}$ in Table 2). Indeed, for B10 nubbins, a significant change in TOC flux direction was observed, which resulted in a measurable TOC net release $\left(0.35 \pm 0.04 \mu \mathrm{g}\right.$ TOC $\left.\mathrm{cm}^{-2} \mathrm{~h}^{-1}\right)$ for all investigated corals (Fig. 5b). This considerable release remained similar after bleached conditions were reached (B21) and continued at comparable levels after the recovery period (B70; Fig. 5b). Subsequent measurements of $S$. pistillata corals maintained at control conditions (C70) also revealed a significant change in TOC net flux direction induced by coral bleaching if compared with the later bleached treatment (B70; Fig. 5b).

\section{DISCUSSION}

The results obtained by this study highlight new energetic aspects of the scleractinian coral Stylophora pistillata, and likely other Pocilloporidae, which impact the coral-algae symbiosis over the course of a thermal and photo stress event. They also might explain why branching coral species such as $S$. pistillata are more affected than other growth forms during a bleaching event (Loya et al. 2001). Our findings indeed reveal that an increase in seawater temperature above $31^{\circ} \mathrm{C}$ not only significantly decreases the auto- and heterotrophic supply of $\mathrm{C}$ and other nutrients in $S$. pistillata, but also increases the loss of organic C. As a consequence, the energetic budget of bleached colonies of $S$. pistillata is severely impacted. Another novel aspect of this study is the quantitative assessment of $\mathrm{C}$ gained from either pico- and nanoplankton grazing or DOC uptake by a scleractinian coral under control and stressed conditions. 


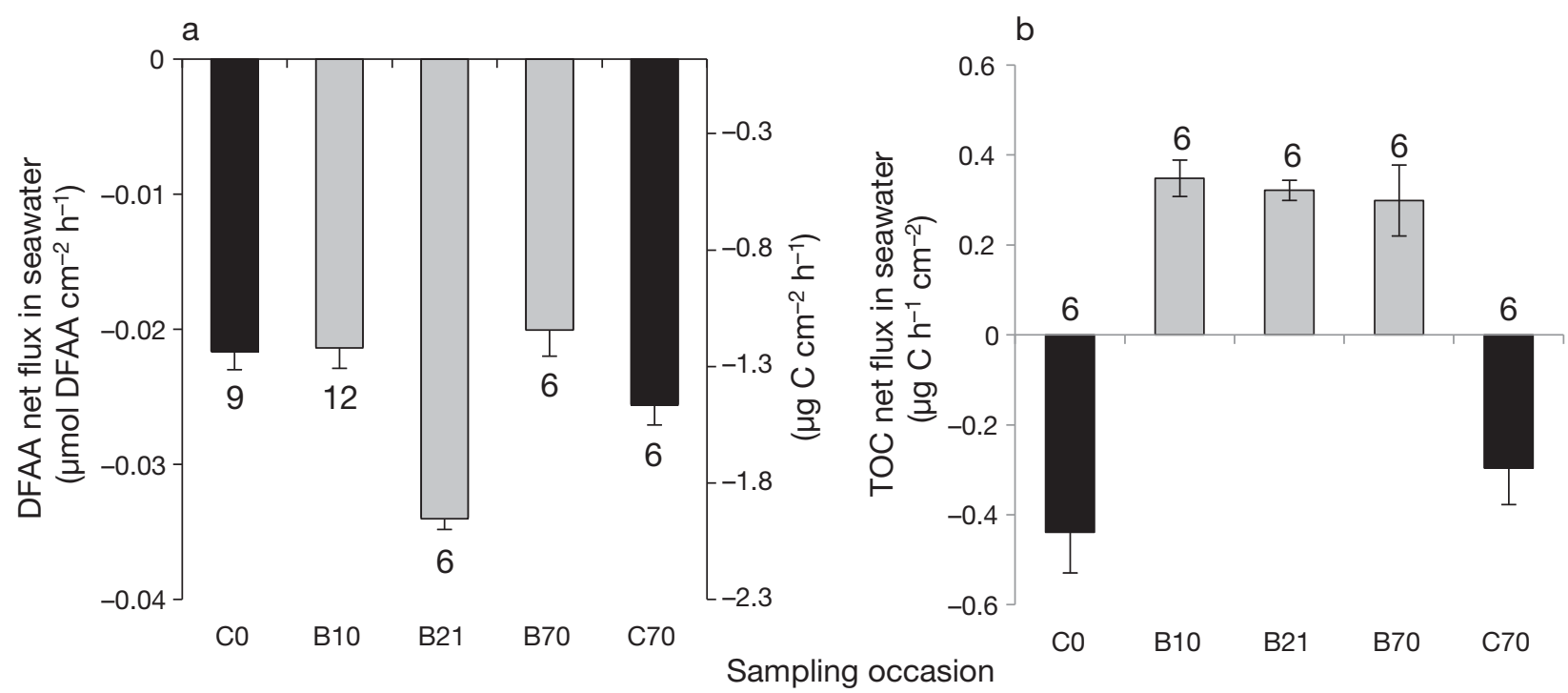

Fig. 5. Stylophora pistillata. (a) Dissolved free amino acid (DFAA) net flux (at initial concentration of $3.50 \pm 0.09 \mu \mathrm{M}$ DFAA) expressed as $\mu$ mol DFAA cm ${ }^{-2} \mathrm{~h}^{-1}$ or $\mu \mathrm{g} \mathrm{C} \mathrm{cm}^{-2} \mathrm{~h}^{-1}$, and (b) total organic carbon (TOC) net flux expressed as $\mu \mathrm{g} \mathrm{C} \mathrm{cm}^{-2} \mathrm{~h}^{-1}$ in $S$. pistillata over the course of a thermal and light stress event. Data are means \pm SE and the sample sizes (n) are displayed above or below the bars. For sample abbreviations, see Fig. 1 legend

Table 2. Results of ANOVA on the before-after, controlimpact (BACI) design testing the effect of thermal and photo stress on dissolved free amino acid (DFAA) and total organic carbon (TOC) net fluxes in Stylophora pistillata. Significant values are in bold

\begin{tabular}{|lrcc|}
\hline Factor & df & p & $F$ \\
\hline DFAA net flux & & & \\
Period: Before-After (BA) & 1 & $\mathbf{0 . 0 0 4 2}$ & 9.52 \\
Treatment: Control-Bleach (CI) & 1 & 0.1836 & 1.85 \\
Period $\times$ Treatment (BA $\times$ CI) & 1 & 0.1914 & 1.78 \\
Times within period (T[BA]) & 2 & $<\mathbf{0 . 0 0 0 1}$ & 15.62 \\
Error & 32 & - & - \\
TOC net flux & & & \\
Period: Before-After (BA) & 1 & $<\mathbf{0 . 0 0 0 1}$ & 29.83 \\
Treatment: Control-Bleach (CI) & 1 & $<\mathbf{0 . 0 0 0 1}$ & 26.74 \\
Period $\times$ Treatment (BA $\times$ CI) & 1 & $\mathbf{0 . 0 3 8 5}$ & 4.84 \\
Times within period (T[BA]) & 2 & 0.8455 & 0.17 \\
Error & 22 & - & - \\
\hline
\end{tabular}

\section{Role of grazing on microorganisms and DOC uptake in organic carbon fluxes}

Under control conditions (C0 and C70), Stylophora pistillata efficiently acquires $\mathrm{C}$ and other nutrients through both auto- and heterotrophy. Most of the respiratory requirements are satisfied by photosynthesis (CZAR equal to ca. 94\%; Fig. 2c). Grazing rates on pico- and nanoplankton are in the same range as previously measured for the same species (Houlbrèque et al. 2004) and represent ca. 11\% of the $\mathrm{C}$ provided by photosynthesis (CHAR equal to
$10.6 \%)$. As another source of nutrients, S. pistillata is able to efficiently take up DFAA, as previously observed (Grover et al. 2008), although this uptake contributes more to the acquisition of $\mathrm{N}$ than $\mathrm{C}$ (the CHAR corresponding to the DFAA uptake rates is equal to ca. $10 \%$ at $3.5 \mu \mathrm{M}$, but such concentrations are higher than those observed in reef waters; Palenik \& Morel 1990, Ferrier 1991, Bronk 2002). Nevertheless, under control conditions, net TOC flux is negative, indicating that $S$. pistillata represents a net TOC sink, likely defined by a predominant uptake of DOC and POC (as highlighted by DFAA uptake rates and pico- and nanoplankton grazing rates) and a quantitatively lower release of POC. This is in line with previous findings in other coral species, such as Pocillopora sp. or Fungia sp. (Naumann et al. 2010a). Although TOC net uptake was in the lower range of rates reported by Naumann et al. (2010a), ca. $-0.77 \mu \mathrm{g}$ TOC $\mathrm{cm}^{-2} \mathrm{~h}^{-1}$, CHAR was equal to 4.5 to $6.2 \%$, thus confirming that more $\mathrm{C}$ is gained from seawater.

Taking into account all dissolved and microparticulate $\mathrm{C}$ sources, control colonies ( $\mathrm{C} 0$ and $\mathrm{C} 70$ ) of Stylophora pistillata gain ca. $26 \mu \mathrm{g} \mathrm{C} \mathrm{cm}^{-2} \mathrm{~d}^{-1}$ from heterotrophy and ca. $154 \mu \mathrm{g} \mathrm{C} \mathrm{cm}^{-2} \mathrm{~d}^{-1}$ from autotrophy (equal to ca. $110 \%$ of the respiratory needs, $16 \%$ from heterotrophy [picoplankton, nanoplankton and TOC CHAR] and $94 \%$ from autotrophy [CZAR]. Consequently, auto- and heterotrophic $\mathrm{C}$ sources fulfil the daily metabolic requirements of $S$. pistillata under control conditions. 


\section{Effect of thermal and light stress on organic carbon fluxes}

In contrast, when compared with control corals (C0 and C70), long-term bleached colonies (B70), having lost $60 \%$ of their zooxanthellae symbionts, showed substantially (by $50 \%$ ) decreased photosynthesis rates, suggesting that they are unable to sustain their metabolic requirements (CZAR equal to $64 \%$; Fig. 2c) unless they use their energetic reserves or increase their heterotrophic $\mathrm{C}$ input (Grottoli et al. 2006). A previous study performed on the same species found that Stylophora pistillata significantly decreases its feeding rate on microzooplankton (Artemia salina nauplii) under thermal stress, therefore partly losing its heterotrophic capacity compared with normal conditions (Ferrier-Pagès et al. 2010). The present study also demonstrates that bleached colonies of $S$. pistillata, and maybe related coral species, are not able to increase uptake rates of DOC or grazing rates on small particulate food. They even shifted from the capture of larger and energetically more valuable prey during control conditions (i.e. nanoflagellates) to the capture of smaller low-energy prey (i.e. bacteria and picoflagellates) when bleached. This difficulty in capturing larger prey may result from their higher motility and capacity to escape from the polyp tentacles, suggesting a high energetic cost for their capture. Conversely, stressed colonies retain greater amounts of non-motile particles, such as bacteria and picoplankton. Although these food items have a lower energetic value (lower $\mathrm{C}$ content), they are present in high concentrations (i.e. bacteria $>10^{5} \mathrm{ml}^{-1}$ ), and thus catching them may be less time- and energyconsuming. However, this can be considered as a loss in the optimal foraging capacity of the corals (MacArthur \& Pianka 1966), as it has been shown that suspension feeders always try to capture and consume the most caloric food, often represented by large cells (Lehman 1976). As a consequence of lower grazing rates, and increased respiration on some sampling occasions, the contribution of picoand nanoplankton to the coral respiratory demand decreases from $10.6 \%$ to only 2 and $7 \%$ (CHAR value) for $\mathrm{B} 21$ and $\mathrm{B} 70$ corals, respectively, while the contribution of DFAA remains stable (CHAR value equal to $10.5 \%$ ). During short- and mediumterm bleaching, S. pistillata might have relied on its lipid reserves to maintain its metabolism, lipid oxidation likely being a more efficient energy source than heterotrophy for this species (Grottoli et al. 2004). S. pistillata is therefore different from Mon- tipora capitata, for example, which was shown to recover from bleaching by relying on zooplankton feeding (Grottoli et al. 2006).

In addition to a lower input of $\mathrm{C}$ by pico- and nanoplankton grazing, stressed corals release substantial amounts of POC and/or DOC into surrounding waters. The significant change in the direction of TOC net flux measured from the onset of bleaching conditions (B10) may indicate increased POC net release, as described by Niggl et al. (2009). A possible change in the direction of DOC net flux is unclear and cannot be resolved from the TOC data herein. However, Niggl et al. (2009) found no significant change in DOC net flux under bleaching or bleached conditions, and this is in line with our findings of continuous DFAA uptake regardless of thermal and light conditions. Expulsion of zooxanthellae may represent a source of released $\mathrm{POC}_{\text {; }}$ however, this has already been considered in the presented TOC net flux rates. More likely, the observed TOC net release may have represented an increased release of mucus POC resulting from a higher abundance of mucus-producing epidermal cells in bleaching and bleached corals (B10, B21 and B70) under thermal stress (Brown 1997). In addition, the increased mucus POC release may represent a host strategy to limit the onset of photoinhibition of its zooxanthellae symbionts (Wooldridge 2009), as excretion of mucus occurred at the very beginning of the heat stress. This may also reflect the loss of the zooxanthellae, which began only a few days later, followed by a decrease in the rates of photosynthesis a few weeks later. This early excretion of mucus is in agreement with the previous observations of increased abundance of mucocytes in the oral tissue layer or enhanced presence of lipid globules within host gastroderm cells during the early stages of thermal bleaching (Salih et al. 1998, Piggot et al. 2009).

Continued TOC net release in $\mathrm{B} 70$ corals, even after the return to control conditions, suggests that heat stress may affect the coral-algae symbiosis over significant periods of time. This is likely dominated by the breakdown of enzymatic pathways, which can result in metabolic and biochemical dysfunction (Cossins \& Bowler 1987). Interestingly, significant mucus release took place even at a significantly diminished abundance of photosynthate-providing zooxanthellae. This suggests that other energy sources, such as lipid reserves, may compensate for the loss in zooxanthellae symbionts. However, as corals were maintained unfed for the duration of the experiment, and the effect of feeding is cancelled quite 
rapidly, lipid pools may have been substantially reduced in $\mathrm{B} 70$ corals, leaving only the uptake of dissolved organic compounds and/or pico- and nanoplankton grazing as a possible solution for the continuous temperature-stress-induced release of TOC. The uptake of DFAA indeed remained unchanged throughout the entire experiment, except for a slight increase of rates in B21 nubbins. These rates are slightly higher than those previously measured for several scleractinian species (Ferrier 1991), Pocillopora damicornis (Hoegh-Guldberg \& Williamson 1999) and Stylophora pistillata (0.004-0.012 $\mu \mathrm{mol}$ DFAA cm ${ }^{-2} \mathrm{~h}^{-1}$ at approximately the same concentration of $3 \mu \mathrm{M}$; Grover et al. 2002).

If all the dissolved and micro-C sources are taken into account, long-term bleached Stylophora pistillata (B70) gained ca. $9 \mu \mathrm{g} \mathrm{C} \mathrm{cm} \mathrm{cm}^{-2} \mathrm{~d}^{-1}$ from micro-

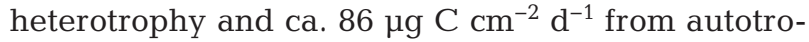
phy (equal to ca. $71 \%$ of its respiratory demands only, $7 \%$ from pico- and nanoplankton CHAR and $64 \%$ from CZAR) and lost ca. $7 \mu \mathrm{g} \mathrm{C} \mathrm{cm}{ }^{-2} \mathrm{~d}^{-1}$ from TOC. Consequently, the ability to sustain its demand for energy while being bleached and recovering is limited by stored energy reserves.

Energy reserves and heterotrophic capabilities of the coral host play key roles in the resilience of particular coral species to thermal bleaching (Grottoli et al. 2006). In the present climate, bleaching events occur globally and have increased dramatically in frequency and duration, putting significant pressure on coral reefs and, in particular, scleractinian corals, as the principal reef ecosystem engineers (HoeghGuldberg 1999, Wild et al. 2011). Corals such as Stylophora pistillata are most likely more susceptible to mortality during prolonged bleaching events as a result of their low-CHAR capacities, i.e. a low capacity to increase their heterotrophic input. Conclusively, time between bleaching events may not be sufficient for these species to replenish their energy reserves, which could result in lowered reproductive output and an ecological disadvantage compared with coral species with high-CHAR capabilities, such as Montipora capitata (Grottoli et al. 2006).

Acknowledgements. We thank C. Rottier (Centre Scientifique de Monaco [CSM]), T. Tanaka and S. Alliouane (Laboratoire d'Océanographie de Villefranche) for invaluable logistical and technical support, and D. Allemand, Director of the CSM, for financial and scientific support. We also thank 4 anonymous reviewers for helpful comments on an earlier version of this paper. Funding for this project was provided by the CSM and the Natural Sciences and Engineering Research Council of Canada (grant no. ES D3-378797-2009).

\section{LITERATURE CITED}

Al-Moghrabi S, Allemand D, Jaubert J (1993) Valine uptake by the scleractinian coral Galaxea fascicularis: characterization and effect of light and nutritional status. J Comp Physiol B 163:355-362

Anthony KRN, Fabricius KE (2000) Shifting roles of heterotrophy and autotrophy in coral energy budgets at variable turbidity. J Exp Mar Biol Ecol 252:221-253

> Anthony KRN, Hoogenboom MO, Maynard JA, Grottoli AG, Middlebrook R (2009) Energetics approach to predicting mortality risk from environmental stress: a case study of coral bleaching. Funct Ecol 23:539-550

Bak RPM, Joenje M, de Jong I, Lambrechts DYM, Nieuwland $G$ (1998) Bacterial suspension feeding by coral reef benthic organisms. Mar Ecol Prog Ser 175:285-288

> Baker AC, Starger CJ, McClanahan TR, Glynn PW (2004) Coral reefs: corals' adaptive response to climate change. Nature 430:741

> Berkelmans R, van Oppen MJH (2006) The role of zooxanthellae in the thermal tolerance of corals: a 'nugget of hope' for coral reefs in an era of climate change. Proc Biol Sci 273:2305-2312

Borell EM, Yuliantri AR, Bischof K, Richter C (2008) The effect of heterotrophy on photosynthesis and tissue composition of two scleractinian corals under elevated temperature. J Exp Mar Biol Ecol 364:116-123

Bronk AD (2002) Dynamics of dissolved organic nitrogen. In: Hansell DA, Carison CA (eds) Biogeochemistry of marine dissolved organic matter. Academic Press, San Diego, CA, p 153-247

$>$ Brown BE (1997) Coral bleaching: causes and consequences. Coral Reefs 16:S129-S138

Buddemeier RW, Kleypas JA, Aronson R (2004) Coral reefs and global climate change. Potential contributions of climate change to stresses on coral reef ecosystems. Pew Center on Global Climate Change, Arlington, VA

Bythell JC (1988) A total nitrogen and carbon budget for the elkhorn coral Acropora palmata (Lamarck). Proc 6th Int Coral Reef Symp 2:535-540

Coffroth MA (1984) Ingestion and incorporation of coral mucus aggregates by a gorgonian soft coral. Mar Ecol Prog Ser 17:193-199

Cossins AR, Bowler K (1987) Temperature biology of animals. Chapman \& Hall, New York, NY

> Donner SD, Skirving WJ, Little CM, Oppenheimer M, Hoegh-Guldberg O (2005) Global assessment of coral bleaching and required rates of adaptation under climate change. Glob Change Biol 11:2251-2265

> Douglas AE (2003) Coral bleaching: how and why? Mar Pollut Bull 46:385-392

Drollet JH, Faucon M, Martin PMV (1995) Elevated seawater temperature and solar UV-B flux associated with two successive coral mass bleaching events in Tahiti. Mar Freshw Res 46:1153-1157

- Edge SE, Morgan MB, Gleason DF, Snell TW (2005) Development of a coral cDNA array to examine gene expression profiles in Montastraea faveolata exposed to environmental stress. Mar Pollut Bull 51:507-523

- Edmunds PJ (1994) Evidence that reef-wide patterns of coral bleaching may be the result of the distribution of bleaching-susceptible clones. Mar Biol 121:137-142

$>$ Ferrier MD (1991) Net uptake of dissolved free amino acids by four scleractinian corals. Coral Reefs 10:183-187

> Ferrier-Pagès C, Gattuso JP (1998) Biomass, production and 
grazing rates of pico- and nanoplankton in coral reef waters (Miyako Island, Japan). Microb Ecol 35:46-57

- Ferrier-Pagès C, Gattuso JP, Cauwet G, Jaubert J, Allemand D (1998) Release of dissolved organic carbon and nitrogen by the zooxanthellate coral Galaxea fascicularis. Mar Ecol Prog Ser 172:265-274

Ferrier-Pagès C, Schoelzke V, Jaubert J, Muscatine L, Hoegh-Guldberg O (2001) Response of a scleractinian coral, Stylophora pistillata, to iron and nitrate enrichment. J Exp Mar Biol Ecol 259:249-261

Ferrier-Pagès C, Rottier C, Béraud É, Levy O (2010) Experimental assessment of the feeding effort of three scleractinian coral species during a thermal stress: effect on the rates of photosynthesis. J Exp Mar Biol Ecol 390:118-124

Ferrier-Pagès C, Hoogenboom M, Houlbrèque F (2011) The role of plankton in coral trophodynamics. In: Dubinsky Z, Stambler N (eds) Coral reefs: an ecosystem in transition. Springer, Heidelberg, p 215-229

Fitt WK, Brown BE, Warner ME, Dunne RP (2001) Coral bleaching: interpretation of thermal tolerance limits and thermal thresholds in tropical corals. Coral Reefs 20: 51-65

> Fitt WK, Gates RD, Hoegh-Guldberg O, Bythell JC and others (2009) Response of two species of Indo-Pacific corals, Porites cylindrica and Stylophora pistillata, to short-term thermal stress: the host does matter in determining the tolerance of corals to bleaching. J Exp Mar Biol Ecol 373:102-110

Frost BW (1972) Effects of size and concentration of food particles on the feeding behavior of the marine planktonic copepod Calanus pacificus. Limnol Oceanogr 17:805-815

Glynn PW (1996) Coral reef bleaching: facts, hypotheses and implications. Glob Change Biol 2:495-509

Green RH (1979) Sampling design and statistical methods for environmental biologists. Wiley Interscience, Chichester

> Grottoli AG, Rodrigues LJ, Juarez C (2004) Lipids and stable carbon isotopes in two species of Hawaiian corals, Porites compressa and Montipora verrucosa, following a bleaching event. Mar Biol 145:621-631

Grottoli AG, Rodrigues LJ, Palardy JE (2006) Heterotrophic plasticity and resilience in bleached corals. Nature 440: 1186-1189

> Grover R, Maguer JF, Reynaud-Vaganay S, Ferrier-Pagès C (2002) Uptake of ammonium by the scleractinian coral Stylophora pistillata: effect of feeding, light, and ammonium concentrations. Limnol Oceanogr 47:782-790

> Grover R, Maguer JF, Allemand D, Ferrier-Pagès C (2003) Nitrate uptake in the scleractinian coral Stylophora pistillata. Limnol Oceanogr 48:2266-2274

Grover R, Maguer JF, Allemand D, Ferrier-Pagès C (2008) Uptake of dissolved free amino acids by the scleractinian coral Stylophora pistillata. J Exp Biol 211:860-865

> Hedges JI (1992) Global biogeochemical cycles: progress and problems. Mar Chem 39:67-93

> Hoegh-Guldberg O (1999) Climate change, coral bleaching and the future of the world's coral reefs. Mar Freshw Res 50:839-866

$>$ Hoegh-Guldberg O (2011) Coral reef ecosystems and anthropogenic climate change. Reg Environ Change 11(Suppl 1):215-227

> Hoegh-Guldberg O, Smith GJ (1989) The effect of sudden changes in temperature, irradiance and salinity on the population density and export of zooxanthellae from the reef corals Stylophora pistillata Esper and Seriatopora hystrix Dana. J Exp Mar Biol Ecol 129:279-303
Hoegh-Guldberg O, Williamson J (1999) Availability of two forms of dissolved nitrogen to the coral Pocillopora damicornis and its symbiotic zooxanthellae. Mar Biol 133: $561-570$

> Hoogenboom M, Béraud É, Ferrier-Pagès C (2010) Relationship between symbiont density and photosynthetic carbon acquisition in the temperate coral Cladocora caespitosa. Coral Reefs 29:21-29

> Houlbrèque F, Tambutté TE, Richard C, Ferrier-Pagès C (2004) Importance of a micro-diet for scleractinian corals. Mar Ecol Prog Ser 282:151-160

> Houlbrèque F, Delesalle B, Blanchot J, Montel Y, FerrierPagès $C$ (2006) Picoplankton removal by the coral reef community of La Prévoyante, Mayotte Island. Aquat Microb Ecol 44:59-70

Hughes TP, Baird AH, Bellwood DR, Card M and others (2003) Climate change, human impacts, and the resilience of coral reefs. Science 301:929-933

Iglesias-Prieto R, Matta J, Robins WA, Trench RK (1992) Photosynthetic response to elevated temperature in the symbiotic dinoflagellate Symbiodinium microadriaticum in culture. Proc Natl Acad Sci USA 89:10302-10305

Jeffrey SW, Humphrey GF (1975) New spectrophotometric equations for determining chlorophylls $a, b, c_{1}$ and $c_{2}$ in higher plants, algae and natural phytoplankton. Biochem Physiol Pflanz 167:191-194

Kato M (1987) Mucus-sheet formation and discoloration in the reef-building coral, Porites cylindrica: effects of altered salinity and temperature. Galaxea 6:1-16

> Lehman JT (1976) The filter-feeder as an optimal forager, and the predicted shapes of feeding curves. Limnol Oceanogr 21:501-516

> Lesser MP, Farrell J (2004) Exposure to solar radiation increases damage to both host tissues and algal symbionts of corals during thermal stress. Coral Reefs 23: 367-377

> Levy O, Mizrahi L, Chadwick-Furman NE, Achituv Y (2001) Factors controlling the expansion behaviour of Favia favus (Cnidaria: Scleractinia). Effects of light, flow and planktonic prey. Biol Bull 200:118-126

> Loya Y, Sakai K, Yamazata K, Nakano Y, Sambali H, van Woesik R (2001) Coral bleaching: the winners and the losers. Ecol Lett 4:122-131

MacArthur RH, Pianka ER (1966) Optimal use of a patchy environment. Am Nat 100:603-609

> Marshall PA, Baird AH (2000) Bleaching of corals on the great barrier reef: differential susceptibilities among taxa. Coral Reefs 19:155-163

Mass T, Kline DI, Roopin M, Veal CJ, Cohen S, Iluz D, Levy O (2010) The spectral quality of light is a key driver of photosynthesis and photoadaptation in Stylophora pistillata colonies from different depths in the Red Sea. J Exp Biol 213:4084-4091

McCloskey LR, Muscatine L (1984) Production and respiration in the Red Sea coral Stylophora pistillata as a function of depth. Proc R Soc Lond B Biol Sci 222:215-230

Morgan MB, Edge SE, Snell TW (2005) Profiling differential gene expression of corals along a transect of waters adjacent to the Bermuda municipal dump. Mar Pollut Bull 51: 524-533

Muscatine L, McCloskey LR, Marian RE (1981) Estimating the daily contribution of carbon from zooxanthellae to coral animal respiration. Limnol Oceanogr 26:601-611

Muscatine L, Porter JW, Kaplan IR (1989) Resource partitioning by reef corals as determined from stable isotope 
composition. I. $\delta^{13} \mathrm{C}$ of zooxanthellae and animal tissue versus depth. Mar Biol 100:185-193

> Naumann MS, Niggl W, Laforsch C, Glaser G, Wild C (2009) Coral surface area quantification-evaluation of established techniques by comparison with computer tomography. Coral Reefs 28:109-117

Naumann MS, Haas A, Struck U, Mayr C, el-Zibdah M, Wild C (2010a) Organic matter release by the dominant hermatypic corals of the Northern Red Sea. Coral Reefs 29:649-660

Naumann MS, Mayr C, Struck U, Wild C (2010b) Coral mucus stable isotope composition and labeling - experimental evidence for mucus uptake by epizoic acoelomorph worms. Mar Biol 157:2521-2531

Naumann MS, Orejas C, Wild C, Ferrier-Pagès C (2011) First evidence for zooplankton feeding sustaining key physiological processes in a scleractinian cold-water coral. J Exp Biol 214:3570-3576

Niggl W, Glas M, Laforsch C, Mayr C, Wild C (2009) First evidence of coral bleaching stimulating organic matter release by reef corals. Proc 11th Int Coral Reef Symp 2: 905-911

> Palenik B, Morel FMM (1990) Amino acid utilization by marine phytoplankton: a novel mechanism. Limnol Oceanogr 35:260-269

Parsons TR, Maita Y, Lalli CM (1984) Determination of dissolved free amino acids by fluorometric analysis. In: Parsons TR, Maita Y, Ialli CM (eds) A manual of chemical and biological methods for seawater analysis. Pergamon Press, Oxford, p 40-44

> Picciano M, Ferrier-Pagès C (2007) Grazing of pico- and nanoplankton by the Mediterranean red coral Corallium rubrum. Mar Biol 150:773-778

Piggot AM, Fouke BW, Sivaguru M, Sanford RA, Gaskins HR (2009) Change in zooxanthellae and mucocyte tissue density as an adaptive response to environmental stress by the coral, Montastraea annularis. Mar Biol 156:2379-2389

> Porter KG, Feig YS (1980) The use of DAPI for identifying and counting aquatic microflora. Limnol Oceanogr 25: 943-948

> Ribes M, Coma R, Gili JM (1998) Heterotrophic feeding by gorgonian corals with symbiotic zooxanthella. Limnol Oceanogr 43:1170-1179

Ribes M, Coma R, Gili JM (1999) Natural diet and grazing rate of the temperate sponge Dysidea avara (Desmospongiae, Dendroceratida) throughout an annual cycle. Mar Ecol Prog Ser 176:179-190

Ribes M, Coma R, Rossi S (2003) Natural feeding of the temperate asymbiotic octocoral-gorgonian Leptogorgia sarmentosa (Cnidaria: Octocorallia). Mar Ecol Prog Ser 254: 141-150

Rodolfo-Metalpa R, Richard C, Allemand D, Bianchi CN, Morri C, Ferrier-Pagès C (2006) Response of zooxanthellae in symbiosis with the Mediterranean corals Cladocora caespitosa and Oculina patagonica to elevated temperatures. Mar Biol 150:45-55

Rodrigues LJ, Grottoli AG (2007) Energy reserves and metabolism as indicators of coral recovery from bleaching. Limnol Oceanogr 52:1874-1882

Rowan R (2004) Thermal adaptation in reef coral symbionts. Nature 430:742

Salih A, Hoegh-Guldberg O, Cox G (1998) Bleaching responses of symbiotic dinoflagellates in corals: the effects of light and elevated temperature on their morphology and physiology. In: Greenwood JG, Hall NJ (eds) Proc Australian Coral Reef Soc 75th Anniversary Conf, University of Queenland, Brisbane, p 199-216

Sheldon RW, Rassoulzadegan F (1987) A method for measuring plankton production by particle counting. Mar Microb Food Webs 2:29-44

Shick JM, Ferrier-Pagès C, Grover R, Allemand D (2005) Effects of starvation, ammonium concentration, and photosynthesis on the UV-dependent accumulation of mycosporine-like amino acids (MAAs) in the coral Stylophora pistillata. Mar Ecol Prog Ser 295:135-156

Smith EP (2002) BACI design. In: El-Shaarawi AH, Piegorsch WW (eds) Encyclopedia of environmetrics, Vol 1. John Wiley \& Sons Ltd, Chichester, p 141-148

Smith PK, Khrohn RI, Hermanson GT, Malia AK and others (1985) Measurement of protein using bicinchoninic acid. Anal Biochem 150:76-85

Sorokin Y (1991) Parameters of productivity and metabolisms on coral reef ecosystems off central Vietnam. Estuar Coast Shelf Sci 33:259-280

Stewart-Oaten A, Murdoch WW, Parker KR (1986) Environmental impact assessment: 'pseudoreplication' in time? Ecology 67:929-940

Stimson J, Kinzie RA (1991) The temporal pattern and rate of release of zooxanthellae from the reef coral Pocillopora damicornis (Linnaeus) under nitrogen enrichment and control conditions. J Exp Mar Biol Ecol 153:63-74

Stimson J, Sakai K, Sembali H (2002) Interspecific comparison of the symbiotic relationship in corals with high and low rates of bleaching-induced mortality. Coral Reefs 21: 409-421

Tolosa I, Treignier C, Grover R, Ferrier-Pagès C (2011) Impact of feeding and short-term temperature stress on the content and isotopic signature of fatty acids, sterols, and alcohols in the scleractinian coral Turbinaria reniformis. Coral Reefs 30:763-774

Treignier C, Grover R, Ferrier-Pagès C (2008) Effect of light and feeding on the fatty acid and sterol composition of zooxanthellae and host tissue isolated from the scleractinian coral Turbinaria reniformis. Limnol Oceanogr 53: 2702-2710

Tremblay P, Peirano A, Ferrier-Pagès C (2011) Heterotrophy in the Mediterranean symbiotic coral Cladocora caespitosa: comparison with two other scleractinian species. Mar Ecol Prog Ser 422:165-177

Underwood AJ (1994) On beyond BACI: sampling designs that might reliably detect environmental disturbances. Ecol Appl 4:3-15

Wild C, Woyt H, Huettel M (2005) Influence of coral mucus on nutrient fluxes in carbonate sands. Mar Ecol Prog Ser 287:87-98

> Wild C, Niggl W, Naumann MS, Haas AF (2010) Organic matter release by Red Sea coral reef organisms - potential effects on microbial activity and in situ $\mathrm{O}_{2}$ availability. Mar Ecol Prog Ser 411:61-71

Wild C, Hoegh-Guldberg O, Naumann MS, ColomboPallotta MF and others (2011) Climate change impedes scleractinian corals as primary reef ecosystem engineers. Mar Freshw Res 62:205-215

> Wooldridge SA (2009) A new conceptual model for the enhanced release of mucus in symbiotic reef corals during 'bleaching' conditions. Mar Ecol Prog Ser 396: 145-152

Yahel R, Yahel G, Genin A (2005) Near-bottom depletion of zooplankton over coral reefs. I. Diurnal dynamics and size distribution. Coral Reefs 24:75-85 